俣病は昭和28年頃より発症がみられ昭和31年にいたり急 増し昭和35年に 4 例の発症をみて後, それ以後の発症は 認められない．現在までの患者発生総数は 116 名でその 内胎児性又は先天性水俣病は23名で死亡総数45名の内胎 児性水俣病は 3 名である。今回私は胎坚性俣病患者10名 につき䨑牙および口腔内所見を検診する機会を得ました ので一端を報告しました．検診は昭和44年12月より行っ た。 また対象は水俣市立病院附属病院湯の児リハビリテ ーションセンターに入院中の胎児性水俣病患者 9 名之自 宅療養中の胎児性水俣病患者 1 名である，今回の検診に よればエナメル質石灰化不全と思われる歯牙が多数みら れ10例中 7 例に散見された。また一般に覾䨑が多く自宅 療養中の工例に抢いては28本中22本の醨菌の発生をみて

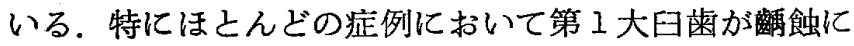
䍜患しその歯冠部は著しく崩壊又は欠如しているが，て れは口腔清掃の不良はいうまでもなく乳歯㐘列期におけ る口腔状態の不良がその原因の重要な要素であると思わ れる．歯列の不正は全症例にみられ，上類前歯部の前突 が 2 例みられ，ほぼ半数に近い症例において過蓋咬合が みられた。なお咀嚼筋群の不随意運動によると考えられ る咬耗症が 5 例あったが，乙れらの患者は介補者の話に よると夜間雨ぎしりをよくするとのことである．また検 診の際最大に開口を命じ開口を行っった直後, 反射的に閉 口咬合し霜ぎしりを $2 \sim 3$ 秒間行っていた，乳歯の晚期 残存や霜数の異常等が数例にみられたが，乙れらについ ては症例を重ね，後日報告したいと思います。

\section{而 疑}

（能大・医・每叶外）田 緣

症例の第3症例に Alveatin の投与が行われているよ うですが Epilepsie のためか, 或は歯痛防止のためで しょうか.

\section{応 答}

（九㐘大・2口外) 伊 藤

全身的必要から抗ケイレン剂として使用されていた。

\section{追加}

(九遴大・2口外) 池 尼

報告した症例 中にアレビアチンを投与されたのは Epirepsie に対してではなく全身ケイレンに対して投与 むれたあのであるが，それがどれ位全身ケイレンに有効 であるかについては確実な成績はありません，

\section{5. 口腔外科項域における Gentamicin の基礎的臨 床的䄃討}

\author{
（九为大外） ○井口次夫 \\ （九菌大・口緗）内山長司
}

Gentamicin (GM) はグラム陽性菌拉よびグラム陰性 菌に対して抗菌作用を示す新しい抗生物質で，今まで有 効な薬剤の少なかった Pseudomonas, Proteus などに あ強い抗菌作用を示すとされている．今回，口腔外科領 域で本剂を使用し，基礎的実験ならびに臨床使用経験に ついてその成績を報告した。

昭和44年 8 月上り昭和 45 年 4 月までに口腔外科領域各 種病巣より分離した菌株の各種薬剂に対する感受性試験 をDisk 法により行った。

ブドウ球菌では全株とも感受性を示した。

レンサ球菌ではCP. SM についで，TC と同じく73\% と，かなりすぐれた成績であった。コリネバクテリウム では CP と同じく，全秼とあ感受性を示した。 また，ブ 菌およびレンサ球菌について，今回の薬郕感受性試験成 績を，昭和40年度および昭和44年 1 月から 5 月における 成績之比較すると，ブ菌では PC, CP の耐性株の減少 がみられた。レンサ球菌では44年度前期に比較して，今 回は TC 耐性株の減少が目立った。

次に同じく病巣分離ブ菌16株について，GM に対する 感受性分布を検討したほとんどの菌株が M. I. C. 0.19 $\mathrm{mcg} / \mathrm{ml}$ 以下であった。 また，健康成人 3 名について本 剂40mg 筋注後の血中濃度を測定したところ，注射12時 間後でも $0.28 \mathrm{mcg} / \mathrm{ml}$ が検出され，本剤の持続が長い 事を認めた。

臨床的には，急性澦骨々膜炎など17例に使用し，著効 4 , 有効10, 無効 3 例の成績を得た。副作用は全例を通 じて1例屯認められなかった。

\section{6. 下䂓運動の中心}

(九橉大·矮正) ○山田建二郎・藤田邦彦 横田成三

顎運動は蒾学全般の基礎をなすむので，矯正学におい ても，顎の移動を行なう関係上，また，機能的咬合状態 に歯列矯正しようとする意味からむ，早急に解明される べき問題である，今回，我々は，上下顎前歯部に作った レジンキャップに，メルクマールを取りつけ，写真撮影 して先に教室の上川らの発表した「下顎運動の中心を精 密に計測する装置」（九州歯学雑誌, 19:246-250) の 理論に基づいて，顎の運動様相を解析した。

次の四項目について，下顎切歯路，および顎運動の中 